\title{
COMPARISON OF PARTICULATE ORGANIC AND DISSOLVED INORGANIC RADIOCARBON SIGNATURES IN THE SURFACE NORTHEAST PACIFIC OCEAN
}

\author{
Chanda Bertrand ${ }^{1}$ B Brett Walker • Sheila Griffin • E R M Druffel \\ Department of Earth System Science, University of California Irvine, Irvine, California 92697-3100, USA.
}

\begin{abstract}
It has long been assumed that radiocarbon $\left(\Delta^{14} \mathrm{C}\right)$ content of dissolved inorganic carbon (DIC) is equal to that of particulate organic carbon (POC) in surface seawater; however, little research has been conducted to explicitly test this assumption. Here, we report $\Delta^{14} \mathrm{C}$ measurements of surface POC samples and compare them with contemporaneous DIC $\Delta^{14} \mathrm{C}$ measurements from the northeast Pacific Ocean (Hwang et al. 2004; Druffel et al. 2010). Samples were collected from surface waters at Station M off California between 1995 and 2004. The POC $\Delta^{14} \mathrm{C}$ values decreased 3.2\% per year from 1995 to 2004 , similar to the decline observed in the DIC $\Delta^{14} \mathrm{C}$ values during the same period. Overall, our results show no statistical difference between POC and DIC $\Delta^{14} \mathrm{C}$ - consistent with the assumption that DIC and POC $\Delta^{14} \mathrm{C}$ values can generally be considered equivalent. However, significant variability was observed for POC $\Delta^{14} \mathrm{C}$ values during several fall/summer events, where POC $\Delta^{14} \mathrm{C}$ signatures were lower than DIC $\Delta^{14} \mathrm{C}$ values. An evaluation of 2 sample pretreatments also suggests that non-homogenized POC samples deviated less from average POC $\Delta^{14} \mathrm{C}$ values and more closely matched the DIC $\Delta^{14} \mathrm{C}$ average for the time series. The presence of seasonal POC/DIC $\Delta^{14} \mathrm{C}$ disagreements, combined with sample processing effects, suggest that infrequent contributions of allochthonous, older carbon may have originated from deeper in the water column, especially during periods when upwelling in this area was prominent.
\end{abstract}

\section{INTRODUCTION}

Particulate organic carbon (POC) is largely comprised of both primary and secondary producers in the surface euphotic ocean. Despite the relatively small inventory of carbon in marine POC, dissolved inorganic carbon (DIC) and aqueous carbon dioxide are used by phytoplankton during biosynthesis, so POC fluxes represent a key export mechanism of atmospheric $\mathrm{CO}_{2}$ to the deep ocean via the biological pump (Alldredge and Silver 1988; Longhurst and Harrison 1989; Alldredge et al. 1993). Radiocarbon signatures (as $\Delta^{14} \mathrm{C}$ ) are often used to interpret the relative reactivity of POC in the surface ocean and export of carbon below the permanent thermocline in the ocean, and thus the efficiency of the biological pump. Such estimates are key to reconciling carbon budgets in the surface ocean and our knowledge of the marine carbon cycle.

Previous work has shown that in nutrient-rich waters phytoplankton can comprise up to $80 \%$ of the POC pool (Hobson et al. 1973; Laws et al. 1988). However, bacterial biomass and non-living organic matter are also considered important contributors to the POC pool (i.e. in oligotrophic environments; Cho and Azam 1990; Fowler and Knauer 1986). This incorporation of DIC into the POC pool has led to the common assumption that DIC and POC $\Delta^{14} \mathrm{C}$ signatures are equal in the euphotic zone. However, previous studies reporting $\Delta^{14} \mathrm{C}$ values of organisms from the water column have observed differences from surface DIC collected from the same year in the North Pacific Ocean (Williams and Linick 1975; Williams et al. 1987; Pearcy and Stuiver 1983). The significant $\Delta^{14} \mathrm{C}$ differences observed were attributed to 2 factors: 1 ) the ${ }^{14} \mathrm{C}$ gradient of "bomb" carbon in surface water DIC during the 1960s and 1970s; and 2) the chronological ages of the organisms. Complicating matters, a direct comparison of contemporaneous DIC and POC from the same sample location has, to our knowledge, not been published.

With the ultimate goal of testing the hypothesis that $\Delta^{14} \mathrm{C}$ signatures of POC approximate those of DIC, here we report $\Delta^{14} \mathrm{C}$ measurements of POC and DIC (Masiello et al. 1998; Druffel et al. 2010) samples collected from the surface water during 10 cruises from 1995-2004 in the northeast Pacific.

${ }^{1}$ Corresponding author. Email: bertranc@uci.edu.

(C) 2013 by the Arizona Board of Regents on behalf of the University of Arizona

Proceedings of the 21st International Radiocarbon Conference edited by A J T Jull \& C Hatté

RADIOCARBON, Vol 55, Nr 2-3, 2013, p 1651-1658 


\section{Bertrand et al.}

We show that DIC and POC $\Delta^{14} \mathrm{C}$ values generally agree. However, differences of $\sim 10 \%$ of POC $\Delta \Delta^{14} \mathrm{C}$ values less than DIC $\Delta{ }^{14} \mathrm{C}$ values were found for some duplicates, suggesting that some variability was present.

\section{METHODS}

Most of the samples reported here were collected from Station M in the northeast Pacific off Point Conception, California $\left(34^{\circ} 50^{\prime} \mathrm{N}, 123^{\circ} 00^{\prime} \mathrm{W}\right)$, located $50 \mathrm{~km}$ west of the base of the continental rise. The site lies within the southward-flowing California Current in the surface. The seasonal countercurrent at the surface in fall and winter and the subsurface undercurrent, mainly confined to the continental slope, flow northward along the California coast (Lynn and Simpson 1987). Five other samples were collected on the continental rise and slope.

Surface seawater samples were collected for DIC at the same time as that for the POC samples using a bucket as described previously (Druffel et al. 2010). POC particles were collected with a 33- $\mu \mathrm{m}$ mesh phytoplankton net using a clean, glass cod-end $(250 \mathrm{~mL})$. The net was deployed for $\sim 30 \mathrm{~min}$ at a depth of $0-0.5 \mathrm{~m}$. One portion of the POC sample was poisoned with a formaldehyde solution, sealed, and stored at room temperature in glass jars for future biological identification of contents. The remainder was filtered using an acidified and combusted all-glass filter rig fitted with a precombusted $\left(500{ }^{\circ} \mathrm{C}, 2 \mathrm{hr}\right), 0.7-\mu \mathrm{m}$ QMA quartz filter. The filter was then frozen immediately at $-20^{\circ} \mathrm{C}$ in cleaned Pyrex ${ }^{\circledR}$ petri dishes or Qorpak ${ }^{\circledR}$ glass jars.

At UCI, a subsample of POC was scraped from the filter using a precleaned spatula and was acidified to $\mathrm{pH}<2$ with $1 \% \mathrm{H}_{3} \mathrm{PO}_{4}$ for $24 \mathrm{hr}$ to remove carbonates, dried under vacuum, then combusted in 9-mm quartz tubes with $\mathrm{CuO}$ and $\mathrm{Ag}$ wire at $900{ }^{\circ} \mathrm{C}$ for $3 \mathrm{hr}$ according to standard techniques (Druffel et al. 1992). In the case of highly variable or small sample $\Delta^{14} \mathrm{C}$ signatures and if more material was available, filters were subsampled again and dried overnight at $50{ }^{\circ} \mathrm{C}$. Dried samples were homogenized using an agate mortar and pestle, split for duplicate analysis before acidification, and re-analyzed for ${ }^{14} \mathrm{C}$. The $\mathrm{CO}_{2}$ from combusted POC was converted to graphite targets (Vogel et al. 1987) at UCI and analyzed by accelerator mass spectrometry (AMS) at the KECK-CCAMS Facility on a NEC 0.5MV 1.5SDH-2 AMS with a 40-sample MCSNICS source (Southon et al. 2004). Uncertainties of the $\Delta^{14} \mathrm{C}$ measurements were $\pm 3 \%$.

\section{RESULTS AND DISCUSSION}

\section{$\Delta^{14} \mathrm{C}$ Signatures and Sample Pretreatment Comparison}

A summary of individual and averaged POC $\Delta^{14} \mathrm{C}$ values are shown together with contemporaneous DIC $\Delta^{14} \mathrm{C}$ values (Druffel et al. 2010) in both Table 1 and Figure 1. Individual $\Delta^{14} \mathrm{C}$ values ranged from $-82 \%$ to $66 \%$. Measurements of initial, non-homogenized POC samples had $\Delta^{14} \mathrm{C}$ values that ranged from $-36 \%$ to $65 \%$ o $\left(\Delta^{14} \mathrm{C}\right.$ average $\left.=37 \pm 23 \%, n=42\right)$. However, substantial offsets between absolute DIC and POC $\Delta^{14} \mathrm{C}$ values were observed within these initial analyses (Table 1, POC $\Delta{ }^{14} \mathrm{C} \# 1$; average $\Delta \Delta^{14} \mathrm{C} 9 \pm 19 \%$ ). This variability, combined with many low POC $\Delta^{14} \mathrm{C}$ values with respect to DIC, motivated us to perform replicate POC $\Delta^{14} \mathrm{C}$ analyses and also to test homogenization pretreatments (see Methods) on 28 of the 42 POC samples. Briefly, the first type of replicate (non-homogenized) was a separate sample taken from a different place on the filter pad (Table 1). The second type of replicate analysis was a subsample from a larger, dried, and homogenized sample taken from a larger portion of the filter pad (italicized values Table 1).

The average POC $\Delta^{14} \mathrm{C}$ values of all replicates, and their standard deviations, appear in the middle of Table 1. The standard deviations are relatively low for 5 of the time periods: spring 1995 (1-2\%); 


\section{Comparison of POC and DIC in the NE Pacific Ocean}

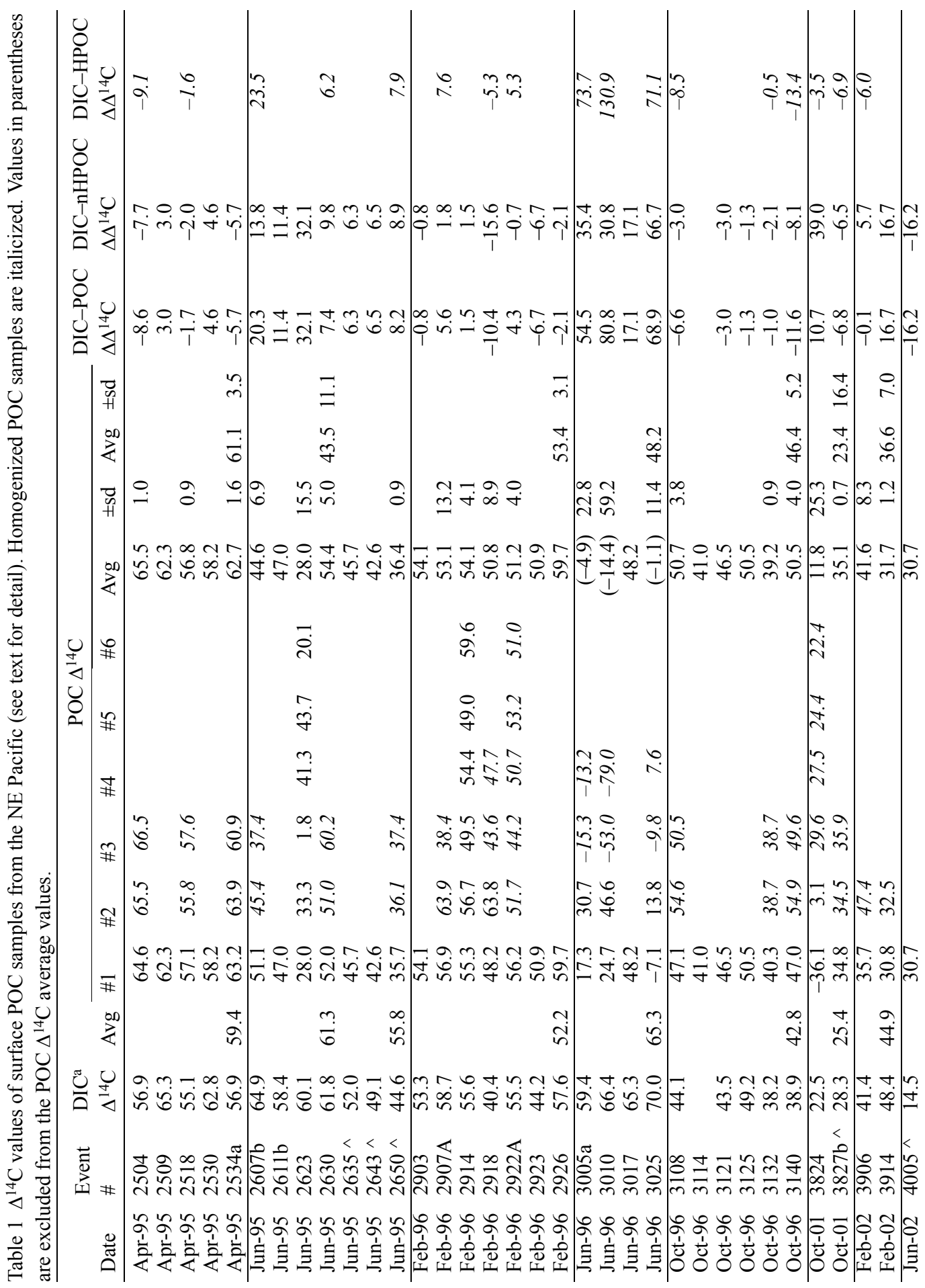




\section{$C$ Bertrand et al.}
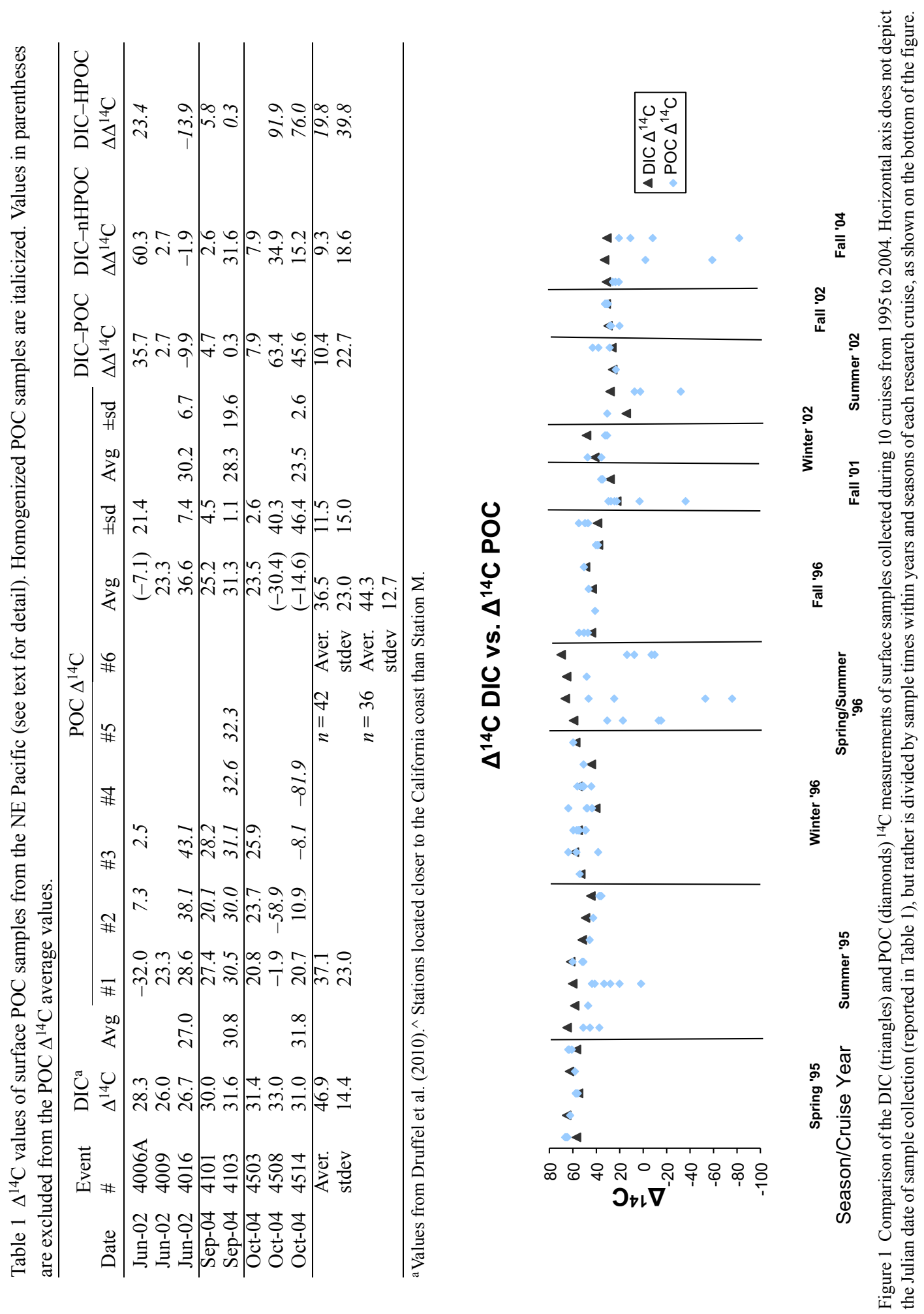
winter $1996(4-13 \%)$ and 2002 (1-8\%); and fall 1996 and late summer 2004 (both 1-4\%o). However, standard deviations are generally higher for the other 5 time periods: summer $1995(1-16 \%)$; 1996 (11-59\%) and 2002 (7-21\%o); and fall 2001 (1-25\%) and 2004 (3-46\%). These differences point to an increase in seasonal variability of POC $\Delta{ }^{14} \mathrm{C}$ values during the early summer (June) and some fall months.

The average of all standard deviation values of all POC $\Delta{ }^{14} \mathrm{C}$ measurements in Table 1 was $11.5 \pm 15.0 \%$ o $(n=28)$. However, significant differences were observed between the 2 sample pretreatments (homogenized vs. non-homogenized). Non-homogenized replicates had, on average, slightly higher standard deviations $( \pm 10.0 \%, n=11)$ versus those of homogenized replicates $( \pm 6.9 \%, n=21)$, indicating more variability in non-homogenized samples. Because there were mixed populations of organisms in the samples, it is likely that there are varying $\Delta{ }^{14} \mathrm{C}$ signatures of organisms from different populations.

\section{Detailed Comparison of POC and DIC $\Delta^{14} \mathrm{C}$ Signatures}

Averaging individual POC sample replicates from both pretreatment methods resulted in an overall POC $\Delta{ }^{14} \mathrm{C}$ average of $36 \pm 23 \%$ for the time series. This average POC $\Delta{ }^{14} \mathrm{C}$ value is slightly lower than the average of all DIC $\Delta^{14} \mathrm{C}$ values determined during the same study (Table $1 ; 47 \pm 14 \%$; Druffel et al. 2010). Model II (geometric mean) regression analysis of all average POC and DIC $\Delta^{14} \mathrm{C}$ values resulted in a weak correlation (Figure $2 ; R^{2}=0.11, p=0.0287$ ). However, by excluding $n=6$ average POC $\Delta{ }^{14} \mathrm{C}$ data points that clearly fell off the trendline (Figure $2, \Delta{ }^{14} \mathrm{C}<10 \%$, open diamonds; sample dates: $5 / 31 / 96,6 / 1 / 96,6 / 3 / 96,6 / 10 / 02,10 / 28 / 04,10 / 29 / 04)$, the regression is significant $\left(R^{2}=0.81, p<0.0001\right)$, suggesting that allochthonous contributions of POC can contribute significant $\Delta^{14} \mathrm{C}$ variability to the POC pool and affect the observed relationship to that of DIC $\Delta^{14} \mathrm{C}$. The $y$ intercept from this regression suggests that POC $\Delta{ }^{14} \mathrm{C}$ values are lower than DIC ${ }^{14} \mathrm{C}$ by $\sim 12 \%$. This result is also confirmed by Student's $t$ tests showing statistically significant differences between all DIC and average POC $\Delta^{14} \mathrm{C}$ values $(d f=81, t=-2.44, p=0.0167)$ versus no difference when these $n=6$ values are excluded $(d f=69, t=-0.75, p=0.4575)$. Together, these results suggest that when anomalous geochemical POC contributions are excluded, POC $\Delta{ }^{14} \mathrm{C}$ is statistically indistinguishable from DIC $\Delta^{14} \mathrm{C}$.

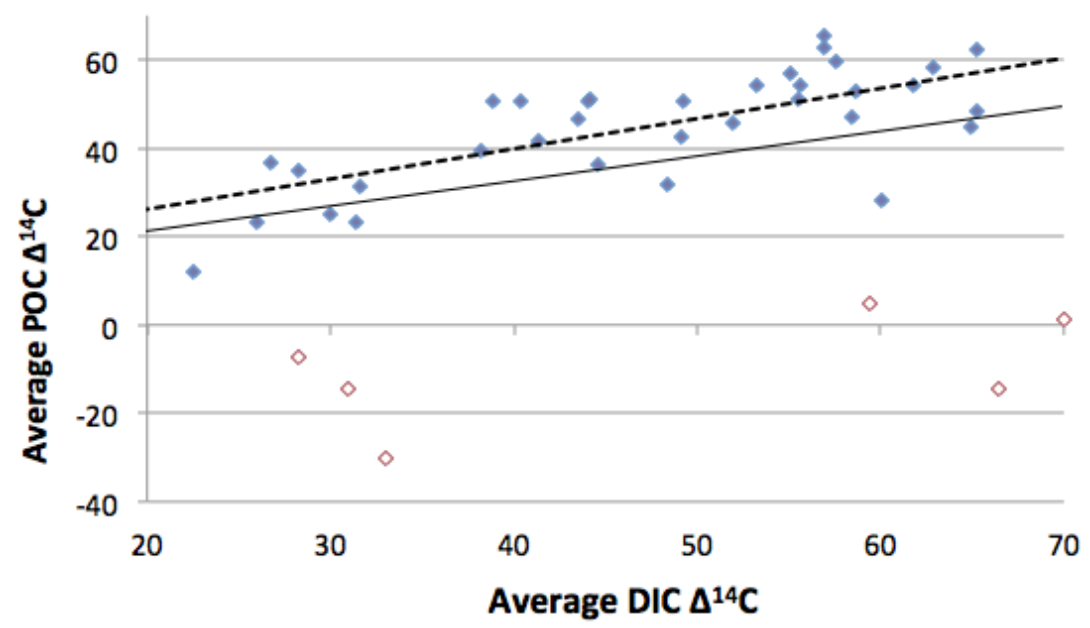

Figure 2 DIC vs. all average POC $\Delta^{14} \mathrm{C}$ values and a Model II (geometric) linear regression reveal $R^{2}=0.11, p=0.0287$ with all data included; $R^{2}=0.81, p<0.0001$ with $n=6$ samples (open diamonds) excluded. Lines (solid, all data included; dashed, 6 samples excluded) are Model I regression lines. 


\section{Bertrand et al.}

Distinguishing between sample pretreatments presents an alternate view of factors contributing to POC $\Delta{ }^{14} \mathrm{C}$ vs. DIC $\Delta^{14} \mathrm{C}$ variability, and also allows for assessment of allochthonous POC sources. Figure $3 \mathrm{~A}$ shows individual comparisons between both sample pretreatments vs. DIC $\Delta^{14} \mathrm{C}$ values. While significant scatter is observed between both sample pretreatments, the homogenized samples are uncorrelated to DIC $\Delta^{14} \mathrm{C}$ values $\left(R^{2}=0.001\right.$, black line). Non-homogenized POC samples were weakly correlated to DIC $\Delta^{14} \mathrm{C}$ values $\left(R^{2}=0.28\right.$, dashed black line). Together this suggests that homogenization does not significantly remove $\Delta^{14} \mathrm{C}$ variability observed within low POC $\Delta^{14} \mathrm{C}$ samples, and again indicates that non-homogenized samples more closely approximate DIC $\Delta^{14} \mathrm{C}$ signatures.
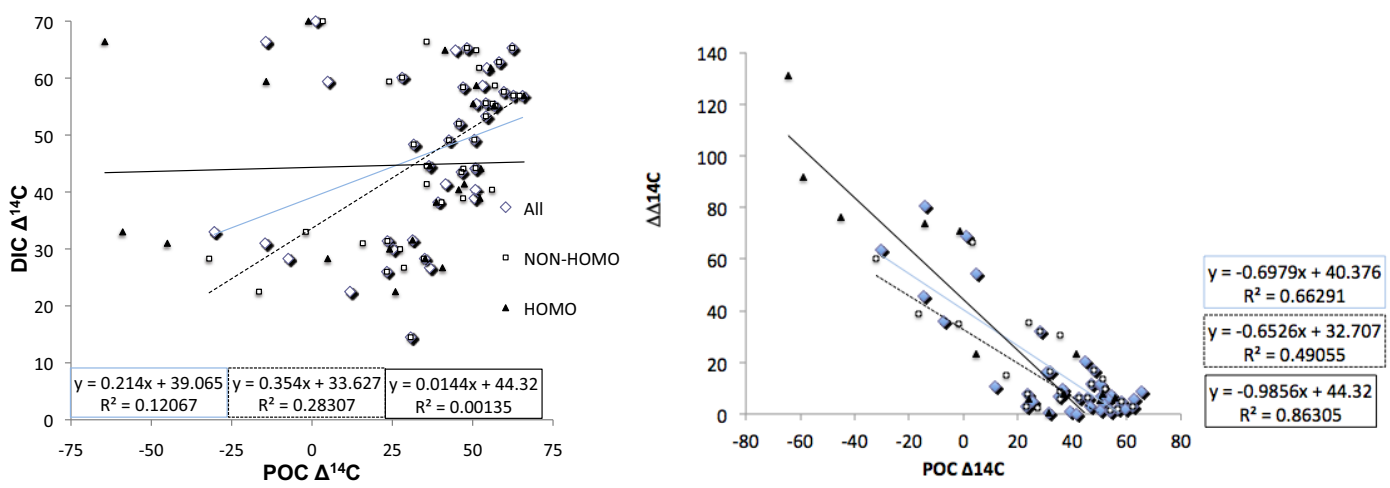

Figure 3 A) left, Comparison of POC pretreatments and $\Delta^{14} \mathrm{C}$ values vs. DIC $\Delta^{14} \mathrm{C}$ values. Blue shows all points. Dashed line shows non-homogenized. Solid line shows homogenized. B) right, Comparison of absolute deviation $\Delta \Delta^{14} \mathrm{C}$ of POC $\Delta^{14} \mathrm{C}$ values from different pretreatments vs. DIC $\Delta^{14} \mathrm{C}$.

Differences between sample pretreatments are further exemplified when the absolute $\Delta^{14} \mathrm{C}$ differences between individual POC and DIC $\Delta^{14} \mathrm{C}$ values are considered $\left(\Delta \Delta^{14} \mathrm{C}\right.$; Figure 3B). Here increasing individual $\Delta \Delta^{14} \mathrm{C}$ values for both sample pretreatments are strongly correlated to decreasing individual POC $\Delta^{14} \mathrm{C}$ values $\left(R^{2} \geq 0.49\right)$. While a shallower slope suggests non-homogenized samples are less affected by low POC $\Delta^{14} \mathrm{C}$ sources, the fact that $\Delta \Delta^{14} \mathrm{C}$ generally increases for both sample pretreatments with low POC $\Delta^{14} \mathrm{C}$ values implicates allochthonous, "pre-aged" POC is a source of POC in the surface ocean at Station M. That is, when the difference between DIC and POC $\Delta^{14} \mathrm{C}$ values is $20-80 \%$, contributions of pre-aged allochthonous (older) carbon to POC are likely. Older C from subsurface POC or DIC pools or perhaps microplastic are potential sources of preaged material. Overall, on the basis of known circulation and productivity patterns at the site, the most likely contributions of pre-aged POC at Station M are the lateral advection of recalcitrant (negative $\Delta^{14} \mathrm{C}$ ), margin-derived suspended POC (Bauer and Druffel 1998; Roland et al. 2008) or perhaps contributions of subsurface material during seasonal upwelling.

\section{Long-Term POC $\Delta^{14} \mathrm{C}$ Trend}

The POC $\Delta{ }^{14} \mathrm{C}$ averages for each cruise are plotted with their corresponding DIC $\Delta^{14} \mathrm{C}$ averages (Figure 4). The least-squares fit line shows POC $\Delta^{14} \mathrm{C}$ values decrease from $\sim 53 \%$ in 1995 to $\sim 25 \%$ in 2004 (Figure 4), compared to that for average DIC $\Delta^{14} \mathrm{C}$ from $58 \%$ to $27 \%$. These decreases are consistent with the diffusion of "bomb" ${ }^{14} \mathrm{C}$ into the surface ocean coupled with convection in the mixed layer and the Suess effect, caused mainly by the input of ${ }^{14} \mathrm{C}$-free $\mathrm{CO}_{2}$ from the burning of fossil fuels. Linear regression analysis shows a decrease of 3.2\% per year $\left(R^{2}=0.825, p<0.005\right)$, consistent with a contemporaneous decrease in DIC $\Delta{ }^{14} \mathrm{C}$ from the same study (3.5\% per year; 


\section{Comparison of POC and DIC in the NE Pacific Ocean}

$\left.R^{2}=0.718, p<0.02\right)$ and recent work showing similar attenuation of the bomb ${ }^{14} \mathrm{C}$ signal during the late 1990s from the Pacific Ocean (Mahadevan 2001). The similarities between POC and DIC $\Delta^{14} \mathrm{C}$ trends also suggest that POC and DIC $\Delta^{14} \mathrm{C}$ signatures generally agree over longer (decadal) timescales.

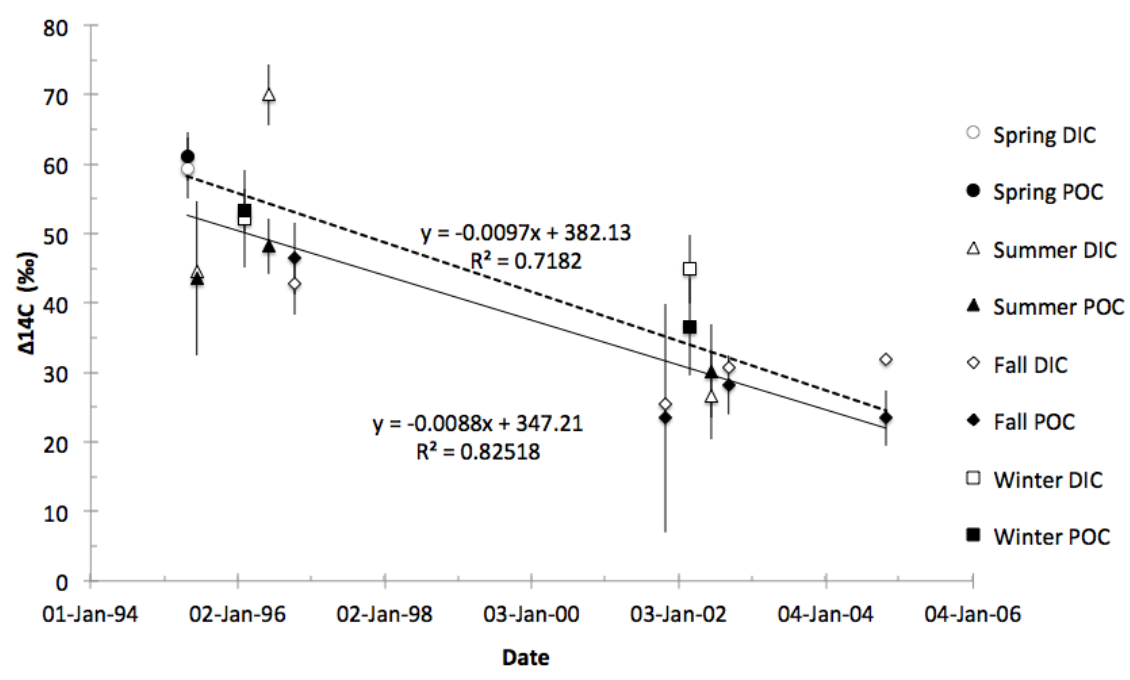

Figure 4 Average of daily surface DIC $\Delta{ }^{14} \mathrm{C}$ values (open symbols) and POC $\Delta{ }^{14} \mathrm{C}$ values (closed symbols) for summer (triangles), spring (circles), fall (diamonds), and winter (squares) cruises versus calendar date with 6 POC $\Delta^{14} \mathrm{C}$ average values removed $(<10 \%)$ (see text for detail). Leastsquares fit lines (Model I) are for POC (black) and DIC (dashed) $\Delta^{14} \mathrm{C}$ values.

\section{ACKNOWLEDGMENTS}

We thank John Southon for advice and support. We acknowledge the Keck Carbon Cycle AMS Lab, NSF Chemical Oceanography program (OCE-0502619 and -0961980) and NSF Office of Polar Programs (ARC-1022716) for funding.

\section{REFERENCES}

Alldredge AL, Silver MW. 1988. Characteristics, dynamics and significance of marine snow. Progress in Oceanography 20(1):41-82.

Alldredge AL, Passow U, Logan BE. 1993. The abundance and significance of a class of large, transparent organic particles in the ocean. Deep-Sea Research I 40(6):1131-40.

Bauer JE, Druffel ERM. 1998. Ocean margins as a significant source of organic matter to the deep open ocean. Nature 392(6675):482-5.

Cho BC, Azam F. 1990. Biogeochemical significance of bacterial biomass in the oceans euphotic zone. Marine Ecology-Progress 63:253-9.

Druffel ERM, Williams PM, Bauer JE, Ertel J. 1992. Cycling of dissolved and particulate organic matter in the open ocean. Journal of Geophysical Research 97(C10): 15,639-59.

Druffel ERM, Beaupré SR, Griffin S, Hwang J. 2010.
Variability of dissolved inorganic radiocarbon at a surface site in the northeast Pacific Ocean. Radiocarbon 52(3):1150-65.

Fowler SW, Knauer GA. 1986. Role of large particles in the transport of elements and organic-compounds through the ocean water column. Progress in Oceanography 16(3):147-94.

Hobson LA, Menzel DW, Barber RT. 1973. Primary productivity and sizes of pools of organic carbon in mixed layer of ocean. Marine Biology 19(4):298-306.

Hwang J, Druffel ERM, Griffin S, Smith Jr KL, Baldwin RJ, Bauer JE. 2004. Temporal variability of $\Delta^{14} \mathrm{C}$, $\delta^{13} \mathrm{C}$, and $\mathrm{C} / \mathrm{N}$ in sinking particulate organic matter at a deep time series station in the northeast Pacific Ocean. Global Biogeochemical Cycles 18: GB4015, doi:10.1029/2004GB002221.

Laws EA, Bienfang PK, Ziemann DA, Conquest LD. 1988. Phytoplankton population-dynamics and the 


\section{Bertrand et al.}

fate of production during the spring bloom in Auke Bay, Alaska. Limnology and Oceanography 33:5765.

Longhurst AR, Harrison WG. 1989. The biological pump: profiles of plankton production and consumption in the upper ocean. Progress in Oceanography 22(1):47-123.

Lynn RJ, Simpson JJ. 1987. The California Current System: the seasonal variability of its physical characteristics. Journal of Geophysical Research 92(C12): 12,947-66.

Mahadevan A. 2001. An analysis of bomb radiocarbon trends in the Pacific. Marine Chemistry 73(3-4):27390.

Masiello CA, Druffel ERM, Bauer JE. 1998. Physical controls on dissolved inorganic radiocarbon variability in the California Current. Deep-Sea Research II 45(4-5):617-42.

Pearcy WG, Stuiver M. 1983. Vertical transport of carbon-14 into deep-sea food webs. Deep-Sea Research A 30(4):427-40.

Roland LA, McCarthy MD, Guilderson T. 2008. Sources of molecularly uncharacterized organic carbon in sinking particles from three ocean basins: a coupled $\Delta^{14} \mathrm{C}$ and $\delta^{13} \mathrm{C}$ approach. Marine Chemistry 111:199213.

Southon J, Santos G, Druffel-Rodriguez K, Druffel E, Trumbore S, Xu XM, Griffin S, Ali S, Mazon M. 2004. The Keck Carbon Cycle AMS laboratory, University of California, Irvine: initial operation and a background surprise. Radiocarbon 46(1):41-9.

Vogel JS, Southon JR, Nelson DE. 1987. Catalyst and binder effects in the use of filamentous graphite for AMS. Nuclear Instruments and Methods in Physics Research B 29(1-2):50-6.

Williams PM, Linick T. 1975. Cycling organic carbon in the ocean: use of naturally occurring radiocarbon as a long and short-term tracer. IAEA Report SM-191-26, Vienna: IAEA. p 53-165.

Williams PM, Druffel ERM, Smith Jr KL. 1987. Dietary carbon sources for deep-sea organisms as inferred from their organic radiocarbon activities. Deep-Sea Research A 34(2):253-66. 